O.V. Vozgoment ${ }^{1}$, M.I. Pykov ${ }^{2}$, N.V. Zaitseva ${ }^{1}$, A.A. Akatova ${ }^{1}$, Yu.A. Ivashova ${ }^{1}$, V.M. Chigvintsev ${ }^{1}$

${ }^{1}$ Federal scientific center for medical and preventive technologies of managing population health risks, Perm, Russian Federation

${ }^{2}$ Russian medical academy of postgraduate education of the Ministry of Health of Russia, Moscow, Russian Federation

\title{
A new ultrasonic criterion of evaluating spleen dimensions in children and determination of the range of normal organ's dimensions
}

\section{Author affiliation:}

Vozgoment Ol'ga Viktorovna, MD, senior research scientist, ultrasonic diagnostician at the Federal scientific center for medical and preventive technologies of managing population health risks (Federal Budgetary Scientific Institution)

Address: 82, Monastyrskaya Str., Perm, 614045; e-mail: vozgom@,fcrisk.ru; tel.: +7 (342) 237-25-34

Article received: 07.02 .2014 . Accepted for publication: 14.05.2014.

The study was aimed at establishing a new ultrasonic criterion of evaluating spleen dimensions in children (area of the maximum axial section) and determining the range of normal spleen dimensions. Patients and methods: We analyzed 838 ultrasonic spleen examinations in 3-15-year-old children and determined the area of the maximum axial section by tracing the scan obtained with a medical device. Results: on the basis of ultrasonic examination data analysis, we established a formula, which helps to calculate the spleen section area with the organ's length and thickness. We performed retrospective analysis of 4,001 standard ultrasonic examinations followed by formula evaluation of the area of maximum axial section. Conclusion: on the basis of the comparative analysis of the measured and calculated areas of the maximum spleen axial section, we established a range of normal values of this parameter taking age and sex into account.

Keywords: spleen, ultrasonic examination, length, thickness, maximum axial section, normal values, children.

Spleen is one of the organs of hematopoiesis and immune protection. Due to its multiple functions, this organ serves as in indicator of numerous pathological conditions induced both by hematological and non-hematological diseases $[1,2]$. Increase in spleen dimensions is caused by accumulation of abnormal red blood cells in sinuses and bands of the pulp [3] and blood pooling in the setting of portal hypertension and heart failure [2,3]. Rarer causes of splenomegaly include a group of storage diseases (Gaucher's disease, amyloidoses), neoplasias, primary spleen tumors, cysts and metastases [1].

Spleen is the largest organ of the peripheral immune system providing immune protection [4]. Immunological disorders and, therefore, increase in spleen dimensions often occur in the setting of exposure to industrial chemical factors $[1,5,6]$.

The size of the spleen indicates its functional status, which is why it is a relevant task for scientists to define the range of standard parameters of this organ.

Ultrasound examination is the most informative, generally available, non-invasive and safe method of appraising spleen dimensions in children, as it allows obtaining the most accurate data on the organ's dimensions and structure. However, the question of the ultrasonic criteria that would outline normal condition of the spleen in children remains disputable.

According to M.I. Pykov and K.V. Vatolin [7], the maximum length of the spleen in a neonate is $45 \mathrm{~mm}$, and it increases each year by $7 \mathrm{~mm}$ reaching the maximum size of $130 \mathrm{~mm}$ by the age of 
12 years. I.V. Dvoryakovskiy et al. [8] suggest appraising linear dimensions of the spleen on the basis of the child's height. According to W.K. Loftus and C. Metreweli [9], the ratio of spleen length to left kidney length is ca. 1.0 in all age groups.

Ultrasound measurement of dimensions accompanied by calculation of the spleen mass coefficient is considered the optimal technique $[10,11]$, as it takes into consideration correlation of linear dimensions of the organs with individual anthropometric parameters of the child - body weight; however, ultrasound examination yields inadequate results if the child's body weight deviates from the norm.

Normal spleen dimensions may be calculated on the basis of the spleen slice area; however, the literature contains data on the normal spleen area range for adults only [12].

Given the increase in the rate of immunopathological diseases in children and, therefore, alteration of spleen dimensions, it is important to employ additional marker criteria of normal dimensions of the organ.

The study was aimed at establishing a new ultrasonic criterion of evaluating spleen dimensions in children (area of the maximum axial section) and determining the range of normal spleen dimensions.

\section{PATIENTS AND METHODS}

At the $1^{\text {st }}$ stage of the study, we measured the area of the maximum axial section in 838 children of 3-15 years of age, who had not had acute diseases and chronic pathology exacerbations within the previous three months and who had not had blood diseases, lymphoproliferative and congenital diseases, as well as cardiovascular and hepatic pathologies, in anamnesis. The examination was performed by means of an expert class device Toshiba Aplio XG SSA-770A using a 3-6 MHz sensor (scanning frequency depends on the child's age and expressiveness of the subcutaneous fat layer). The standard ultrasound examination involved use of an ultrasonic section of the maximum axial dimension of the spleen with simultaneous visualization of splenic hilum. Application of the preinstalled measurement programs helped to lay out the obtained scan and perform automatic calculation of the organ's area (pic.).

At the $2^{\text {nd }}$ stage, we defined a formula, which allows measuring the spleen section area if two spleen dimensions (length and thickness) measured in the framework of the standard ultrasound examination are known.

At the $3^{\text {rd }}$ stage, which took place in 2009-2013, we performed retrospective analysis of 4,001 standard ultrasound examinations of the spleen and, subsequently, calculation of the maximum axial section area of the organ using a design formula. At the final stage, we performed comparative analysis of the measured and calculated values of the maximum axial section area of the spleen and determined the age range of the normal parameters taking sex into consideration.

We used program Statistica 6.1 (USA) to perform statistical analysis of results of the study. Quantitative parameters conforming to the normal distribution law are represented as $\mathrm{M}$ (mean value), $m$ (error in mean), $\sigma$ (standard deviation). Student's t test was used to identify differences of results, which were considered significant at $\mathrm{p} \leq 0.05$ [13]. The obtained data of the normal parameters of spleen section area taking age and sex into consideration are represented as median and interquartile range $\left(0^{\text {th }}\right.$ and $100^{\text {th }}$ percentiles $)$.

\section{STUDY RESULTS AND DISCUSSION}

As a result of the study, we revealed pronounced positive correlation of the maximum axial section area of the spleen with its longitudinal dimension $(r=0.82, p \leq 0.05)$, thickness $(r=0.83$, $\mathrm{p} \leq 0.05)$; the maximum correlation was observed with multiplication of length and thickness of the organ $(r=0.92, p \leq 0.05)$. 
The revealed correlation of the maximum axial section area of the spleen with linear dimensions of the organ allowed formulating a mathematical equation. This formula helps to calculate the spleen section area if two spleen dimensions (length and thickness) measured in the framework of the standard ultrasound examination are known.

The following linear regression model $-y=a^{*} x+b-$ is used to describe dependence of the analyzed data. The least square method was used to calculate parameters $a$ and $b$ of the regression model. The following coefficient values were obtained on the basis of analysis of 838 entries: $a=0.0078$ and $b=0.539$. The dispersion rate of the dependent variable substantiated by the model under consideration under these coefficients is $R^{2}=0.845$. The overall equation subject to mathematical rounding of the dependence values is as follows: $S=0.8 * l * h+0.5$, where $S$ is the maximum axial section area of the spleen $\left(\mathrm{cm}^{2}\right), l-$ spleen length $(\mathrm{cm}), h$ - spleen thickness $(\mathrm{cm})$.

Age analysis of values of maximum axial section area of the spleen performed by means of instrumental methods and calculations is given in tb. 1. Analysis of the age mean group values of the maximum axial section of the spleen in 838 children obtained by tracing the image during the ultrasound examination established that this parameter increases each year by $1.39 \pm 0.42 \mathrm{~cm}^{2}$ on the average. However, this increase is uneven: the maximum increase in section area is observed at the age of 5-7, 8-10 and 12-14 years (see tb. 1).

Comparative analysis of values of maximum axial section area of the spleen obtained instrumentally and calculated using the aforementioned formula demonstrated absence of significant differences $(p>0.05)$ on the basis of ultrasound data of 4,001 children. Thus, the formula may be used to calculate maximum axial section area of the spleen on the basis of retrospective ultrasound data or when the device does not feature this option.

It is necessary to take gender differences into consideration in order to determine the normal range of values of maximum axial section area on the basis of ultrasound data, as physical development of boys and girls is uneven and spleen dimensions depend on anthropometric data. We analyzed values of maximum axial section area of the spleen calculated on the basis of percentiles in boys and girls taking age into consideration (tb. 2).

Analysis of the data under study demonstrated that significant gender differences in the spleen section area are only observed from the age of 14-15 years.

Limits of the specified interval - 5 and $95 \%$ representativeness levels - served as norm inclusion criteria in order to determine the normal range of values of maximum axial section area of the spleen in children and to rule out the risk of determining false values. The studies resulted in an ultimate outcome - a table of normal values of maximum axial section area of the spleen in children taking age and sex into consideration (tb. 3).

\section{CONCLUSIONS}

1. According to the correlation analysis, maximum axial section area of the spleen is a new objective ultrasonic criterion of evaluation dimensions; it is more informative than the analysis of linear spleen dimensions.

2. Maximum axial section area of the spleen in children may be determined either with the standard programs of automatic tracing area measurement (preinstalled into the device) or by means of a calculation based on the standard measurement of spleen length and thickness performed in the course of ultrasound examination using the following formula: $S=0.8 * l * h+0.5$, where $S$ is the maximum axial section area of the spleen $\left(\mathrm{cm}^{2}\right), l-$ spleen length $(\mathrm{cm}), h-$ spleen thickness $(\mathrm{cm})$.

Thus, we established the normal range of ultrasonic values of maximum axial section area of the spleen taking age and sex into consideration on the basis of the obtained data. 


\section{REFERENCES}

1. Naumovich E. G. Kompleksnaya ul'trazvukovaya diagnostika ochagovykh $i$ diffuznykh zabolevanii selezenki. Avtoref. dis...kand. med. nauk [Complex Ultrasound Diagnosis of Focal and Diffuse Diseases of the Spleen. Author's abstract]. Moscow, RMAPO, 2004. 117 p.

2. Naumovich E.G., Mit'kov V.V., Mit'kova M.D. Ul'trazvukovaya i funktsional'naya diagnostika - Ultrasonic and functional diagnostics. 2002; 2: 24-29.

3. Profilakticheskaya pediatriya: Rukovodstvo dlya vrachei. Pod red. A.A. Baranova [Preventive Pediatrics. Guideline. Edited by A.A. Baranov]. Moscow, Soyuz pediatrov Rossii, 2012. 692 p.

4. Drozdov A. A., Drozdova M. V. Zabolevaniya krovi. Polnyi spravochnik [Blood Diseases. Complete Reference Book]. Moscow, Eksmo, 2008. 608 p.

5. Dolgikh O.V., Zaitseva N.V., Dianova D.G. et al. Osobennosti limfotsitarno-kletochnogo zvena u detei, prozhivayushchikh na tekhnogenno nagruzhennykh territoriyakh. Sbornik statei mezhdunarodnoi konferentsii «Retseptory $i$ vnutrikletochnaya signalizatsiya» [Peculiarities of Lymphocytic-cellular Segment in the Children Living in the Industrially Burdened Territories. Collected works of International Conference "Receptors and Intracellular Signaling"]. Pushchino, 2011. pp. 478-483.

6. Vozgoment O. V., Zaitseva N. V., Pykov M. I., Perlova Yu. A., Aminova A. I., Sumenko V. V. Doktor.Ru. - Doctor.Ru. 2013; 9 (87): 69-75.

7. Pykov M.I., Vatolin K.V. Detskaya ul'trazvukovaya diagnostika [Child Ultrasound Diagnostics]. Moscow, Vidar, 2001. 680 p.

8. Dvoryakovskii I.V., Sugak A.B., Dvoryakovskaya G.M. et al. Ul'trazvukovaya $i$ funktsional'naya diagnostika - Ultrasonic and functional diagnostics. 2007; 1: 20-29.

9. Loftus W. K., Metreweli S. Ultrasound assessment of mild splenomegaly: spleen/kidney ratio. Pediatr Radiol. 1998; 28 (2): 98-100.

10. Vozgoment O.V., Pykov M.I., Zaitseva N.V. Ul'trazvukovaya i funktsional'naya diagnostika - Ultrasonic and functional diagnostics. 2013; 6: 56-63.

11. Vozgoment O.V., Zaitseva N.V., Pykov M.I., Kir'yanov D.A., Perlova Yu.A., Patlusova E.S., Chigvintsev V.M. Sposob otsenki sootvetstviya razmerov selezenki norme ili otkloneniya ot nee u detei metodom ul'trazvukovoi diagnostiki. Patent 2502471, Rossiiskaya Federatsiya, MPK A61V. Zayavitel' i patentoobladatel' — Federal'noe byudzhetnoe uchrezhdenie nauki "Federal'nyi nauchnyi tsentr mediko-profilakticheskikh tekhnologii upravleniya riskami zdorov'yu naseleniya» (FBUN «FNTs mediko-profilakticheskikh tekhnologii upravleniya riskami zdorov'yu naseleniya», RU). № 2012136029; zayavl. 21.08.2012; opubl. 27.12.2013, byul. № 36 [Method of Estimating Correspondence of Spleen Dimensions to Norm or Deviation from it in Children by method of ultrasonic diagnostics . Patent No. 2502471, Russian Federation, MPK A61V. Applicant and Proprietor of the Patent - Federal Budgetary Scientific Institution "Federal Scientific Center of Medical-Preventive Public Health Risk Management Technologies" (FBSI "FSC of Medical-Preventive Public Health Risk Management Technologies", RU). No. 2012136029; applied: 21.08.2012; published: 27.12.2013; Bulletin No. 36].

12. Mit'kov V.V. Klinicheskoe rukovodstvo po ul'trazvukovoi diagnostike v 5 tomakh [Clinical Reference on Ultrasound Examination in 5 Volumes]. Moscow, Vidar, 1996.

13. Glants S. Mediko-biologicheskaya statistika [Biomedical Statistics]. Moscow, Praktika, 1999. $459 \mathrm{p}$. 
Pic. Ultrasonic determination of maximum axial section area.

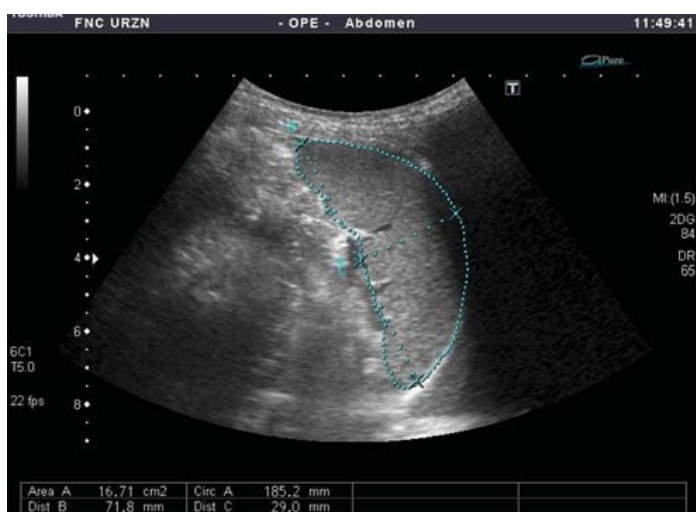

Table 1. Comparative analysis of instrumentally obtained and calculated data on maximum axial section area of the spleen taking age into consideration

\begin{tabular}{|c|c|c|c|c|c|c|c|}
\hline \multirow{2}{*}{ Age, years } & \multicolumn{3}{|c|}{ Instrumental method } & \multicolumn{3}{c|}{ Calculation } & \multirow{2}{*}{ p } \\
\cline { 2 - 7 } & $\mathbf{N}$ & $\mathbf{M} \pm \mathbf{m}, \mathbf{~ c m}^{\mathbf{2}}$ & $\mathbf{S}$ & $\mathbf{N}$ & $\mathbf{M} \pm \mathbf{m},{\mathbf{~} \mathbf{m}^{\mathbf{2}}}^{\mathbf{S}} \mathbf{S}$ & \\
\hline 3 & 37 & $19.4 \pm 1.7$ & 6.1 & 150 & $19.2 \pm 0.7$ & 4.6 & 0.70 \\
\hline 4 & 87 & $20.1 \pm 0.6$ & 2.9 & 397 & $19.7 \pm 0.5$ & 4.8 & 0.30 \\
\hline 5 & 66 & $20.5 \pm 1$ & 3.9 & 589 & $21.4 \pm 0.4$ & 5.1 & 0.09 \\
\hline 6 & 100 & $21.8 \pm 0.91$ & 4.6 & 654 & $22.3 \pm 0.4$ & 5.2 & 0.32 \\
\hline 7 & 104 & $24.0 \pm 0.99$ & 5.1 & 423 & $24.1 \pm 0.5$ & 5.2 & 0.85 \\
\hline 8 & 71 & $25.2 \pm 0.64$ & 2.7 & 268 & $25.6 \pm 0.7$ & 6.1 & 0.42 \\
\hline 9 & 52 & $27.5 \pm 0.89$ & 3.2 & 310 & $26.5 \pm 0.7$ & 6.2 & 0.08 \\
\hline 10 & 63 & $29.1 \pm 1.99$ & 7.5 & 279 & $28.4 \pm 0.9$ & 7.4 & 0.50 \\
\hline 11 & 61 & $31.0 \pm 2.04$ & 8.0 & 256 & $30.7 \pm 0.8$ & 6.6 & 0.79 \\
\hline 12 & 55 & $32.0 \pm 1.62$ & 6.0 & 212 & $32.2 \pm 1.0$ & 7.6 & 0.84 \\
\hline 13 & 49 & $33.8 \pm 2.3$ & 8.0 & 191 & $33.5 \pm 1.1$ & 7.9 & 0.81 \\
\hline 14 & 48 & $35.8 \pm 2.31$ & 7.3 & 162 & $34.8 \pm 1.2$ & 7.5 & 0.46 \\
\hline 15 & 45 & $36.5 \pm 2.39$ & 7.5 & 110 & $36.8 \pm 1.8$ & 9.7 & 0.85 \\
\hline
\end{tabular}

Note. $\mathrm{N}$ - number of studies, $\mathrm{M}$ - mean group value, $\mathrm{S}$ - root-mean-square deviation, $\mathrm{m}$ - error in mean, $\mathrm{p}$ - significance of differences.

Table 2. Percentiles of maximum axial section area of the spleen in children aging from 3 to 15 years

\begin{tabular}{|c|c|c|c|c|c|c|c|c|}
\hline \multirow{2}{*}{ Age, years } & \multirow{2}{*}{$\operatorname{Sex}(n)$} & \multirow{2}{*}{ Minimum value } & \multicolumn{5}{|c|}{ Percentile } & \multirow{2}{*}{ Maximum value } \\
\hline & & & 5 & 25 & 50 & 75 & 95 & \\
\hline \multirow{2}{*}{3} & B (26) & 12.7 & 13.3 & 14.3 & 15.2 & 16.7 & 21.2 & 22.7 \\
\hline & G (21) & 13.5 & 13.5 & 14.7 & 15.9 & 18.3 & 23.9 & 24.7 \\
\hline \multirow{2}{*}{4} & $\mathrm{~B}(51)$ & 12.7 & 14.9 & 16.9 & 18.1 & 19.4 & 23.7 & 25.2 \\
\hline & G (59) & 12.6 & 13.9 & 15.3 & 16.8 & 18.8 & 21.9 & 22.7 \\
\hline \multirow{2}{*}{5} & $\mathrm{~B}(74)$ & 12.8 & 16.2 & 17.3 & 19.6 & 21.6 & 26.6 & 33.1 \\
\hline & G (97) & 12.8 & 14.3 & 17.0 & 18.8 & 21.4 & 26.3 & 34.9 \\
\hline \multirow{2}{*}{6} & $\mathrm{~B}(116)$ & 12.7 & 15.6 & 18.3 & 20.3 & 22.7 & 26.4 & 32.5 \\
\hline & $\mathrm{G}(142)$ & 13.5 & 15.0 & 18.0 & 19.5 & 22.3 & 27.8 & 34.9 \\
\hline \multirow[b]{2}{*}{7} & $\mathrm{~B}(98)$ & 14.4 & 17.3 & 19.3 & 21.9 & 24.4 & 27.7 & 32.7 \\
\hline & G (105) & 14.0 & 17.0 & 19.7 & 21.8 & 23.3 & 27.6 & 38.4 \\
\hline \multirow{2}{*}{8} & $\mathrm{~B}(68)$ & 15.5 & 16.3 & 21.2 & 24.9 & 28.0 & 32.4 & 39.6 \\
\hline & G (74) & 15.0 & 17.8 & 20.7 & 23.0 & 25.7 & 30.1 & 33.5 \\
\hline \multirow{2}{*}{9} & $\mathrm{~B}(86)$ & 18.3 & 19.2 & 22.4 & 26.0 & 28.6 & 34.6 & 45.5 \\
\hline & G (98) & 15.9 & 17.8 & 21.5 & 23.8 & 27.7 & 33.2 & 39.6 \\
\hline
\end{tabular}




\begin{tabular}{|c|c|c|c|c|c|c|c|c|}
\hline \multirow{2}{*}{ Age, years } & \multirow{2}{*}{$\operatorname{Sex}(n)$} & \multirow{2}{*}{ Minimum value } & \multicolumn{5}{|c|}{ Percentile } & \multirow{2}{*}{ Maximum value } \\
\hline & & & 5 & 25 & 50 & 75 & 95 & \\
\hline \multirow{2}{*}{10} & $\mathrm{~B}(76)$ & 17.2 & 20.2 & 23.5 & 26.3 & 29.3 & 35.1 & 44.8 \\
\hline & G (87) & 15.5 & 20.1 & 22.9 & 26.1 & 30.1 & 36.8 & 41.8 \\
\hline \multirow{2}{*}{11} & $\mathrm{~B}(66)$ & 19.8 & 21.9 & 25.4 & 28.5 & 32.2 & 35.8 & 39.5 \\
\hline & $\mathrm{G}(71)$ & 17.1 & 21.6 & 24.6 & 27.7 & 31.3 & 38.9 & 46.7 \\
\hline \multirow{2}{*}{12} & $\mathrm{~B}(62)$ & 21.6 & 24.5 & 27.7 & 30.7 & 35.5 & 42.8 & 56.6 \\
\hline & G (75) & 22.3 & 23.3 & 25.8 & 31.7 & 34.7 & 43.4 & 55.9 \\
\hline \multirow{2}{*}{13} & B (57) & 20.7 & 23.6 & 28.7 & 32.8 & 36.0 & 42.3 & 47.3 \\
\hline & $\mathrm{G}(51)$ & 22.3 & 24.3 & 29.1 & 32.5 & 35.5 & 44.8 & 53.2 \\
\hline \multirow{2}{*}{14} & B (44) & 24.5 & 25.6 & 30.2 & 35.3 & 40.8 & 43.8 & 48.6 \\
\hline & $\mathrm{G}(61)$ & 21.6 & 24.1 & 28.6 & 31.3 & 36.2 & 41.3 & 49.0 \\
\hline \multirow{2}{*}{15} & $\mathrm{~B}(24)$ & 29.0 & 32.2 & 34.8 & 36.8 & 40.4 & 50.6 & 53.7 \\
\hline & G (33) & 22.0 & 24.8 & 29.4 & 32.8 & 34.6 & 41.6 & 46.6 \\
\hline
\end{tabular}

Table 3. Normal maximum axial section area of the spleen on the basis of age and sex

\begin{tabular}{|c|c|}
\hline Age, years & $\mathbf{S}, \mathbf{~ c m}^{\mathbf{2}}$ \\
\hline $3-4$ & $13.3-23.9$ \\
\hline $5-6$ & $14.3-27.8$ \\
\hline $7-8$ & $16.3-32.4$ \\
\hline $9-10$ & $17.8-36.8$ \\
\hline 11 & $21.6-38.9$ \\
\hline $12-14$ & $23.3-44.8$ \\
\hline 15 (girls) & $32.2-50.0$ \\
\hline 15 (boys) & \\
\hline
\end{tabular}

